\title{
Public Relations Management in Efforts to Improve School Image and Community Participation
}

\author{
Daman Rasman Syarif Hidayat \\ Universitas Indraprasta PGRI Jakarta, Indonesia \\ daman@unindra.ac.id
}

\begin{abstract}
Schools and communities are living environment that cannot be separated. A school is a place of learning, while the community environment is a place for the implications of the education and teaching process in schools. In this study, the types of case studies are qualitative. Interviews and literary studies, field observations, and documentation were used for data collection techniques in this study. In this study, the analysis coincided with data collection on the ground. The investigator reduces data obtained in the field by analyzing the data, sorting each information by focusing on research, and drawing conclusions in each direction. Triangulation techniques (sources and methods/technics), observations and member checks are applied to check the validity of the data used in this study. From this research, it can be seen that good public relations or public relations in educational institutions are public relations that can implement the goals, visions and missions that have been set in real terms. The concept and mission are not merely a slogan but are used as the basis for carrying out these public relations duties properly. To make it happen, the vision and mission of public relations in educational institutions need to be supported and the active role of various components in the educational institution, both principals, teachers including all members of the school or educational institution. Finally, so that positive public opinion towards an educational institution can be realized, the development of the vision and mission of public relations in educational institutions based on customer satisfaction can be used as a choice for the achievement of the expected goals.
\end{abstract}

\section{Keywords}

public relations; management; education; school image

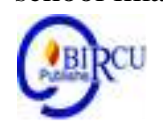

\section{Introduction}

The educational environment exists and occurs in the educational process because groups of objects or the educational climate develop themselves. In this case, education management pays attention to the environment in humans, namely the community, in realizing a quality education process (Bello, Lovelock \& Carr, 2017). What and how to learn in school is always associated with its usefulness for improving life and life in society (Carlson, Wyllie, Rahman \& Voola, 2019). The community, as one of the school owners, supports and participates in improving education in schools. Schools and districts maintain very close contact continuously.

To create a harmonious situation and condition between the school management and the community, cooperation and contact from both parties are urgently needed simultaneously and comprehensively (Di Maddaloni \& Davis, 2017). The strategies used to manage these relationships will be described in the following discussion. Critical management in schools is public relations management because schools are in the midst of society and are always in touch in establishing pedagogical and sociological cooperation 
that benefits both parties (Filipe, Renedo \& Martson, 2017). Public relations have been formulated in different ways depending on the institution or organization that made the formulation (Ferguson, 2018).

Departing from the starting point of this thought, it is necessary to regulate the relationship between the school and the community (Haldane, Chuah, Srivatasva \& Legido, 2019). Public relations with schools is one part of the substance of school education administration. With the relationship between the school and the district, the school can find out the resources that exist in the community, which are then used to benefit the progress of children's education at school (Hasanudin, 2021; Sidiq \& Jalil, 2021). On the other hand, the community can also help by participating in learning and absorbing school knowledge (Irmayani, Wardiah \& Kristiawan, 2018). From here people's lives will be improved. Therefore, the community can understand and understand the purpose of education and the implementation of education in the school (Hasanudin \& Awaloedin, 2020).

It is undeniable that the community and schools are related and play a role in each other. Especially in this day and age, the government has socialized the existence of decentralization of education where schools have the right to manage their schools (Ishimaru, 2019). Public relations with education are highly correlated, even like a chicken with its egg. Advanced society because of education and advanced education will only be found in a progressive community as well (Ji, Li, North \& Liu, 2017).

One of the closest ways to improve quality and relevance is democratization, participation and accountability in education (Kapera, 2018). Principals, teachers and the community are the main and foremost actors in implementing instruction in schools. All decisions regarding the handling of educational problems must have resulted from the interaction of these three parties (Kumar \& Nanda, 2019). The community is an educational stakeholder interested in education success in schools because they are the payers of education, both through tuition and taxes, so schools should be responsible for the community (Nurwulandari, Hasanudin \& Melati, 2021).

In this era of globalization, the role of educational institutions is increasingly required to provide professional management and services to the community (Oakes, Maier \& Daniel, 2017). This is partly due to the increasing public interest and need for education. As customers and users of educational institutions today, the public tend to be more critical and realistic in choosing educational institutions (Sadiqi, Trigunarsyah \& Coffey, 2017). The community's attitude, either directly or indirectly, requires educational institutions to maintain and continuously improve the positive image of the institution in the hearts of the community (Singgalen, Sasongko \& Wiloso, 2019).

To maintain this positive image, apart from continuously improving quality, it is also necessary to have the professionalism of public relations practitioners at the institution (Sullivan, Winses, Akesson \& Lundberg, 2018). This is partly because the role and function of public relations cannot be separated from public opinion (Sidiq \& Achmad, 2020). Good management of public opinion can foster active and productive public participation and support for educational institutions so that public relations practitioners who can understand their duties and functions properly are necessary to construct reasonable public opinion on the image of the institution (Theadom, Starkey, Barker \& Feigin, 2018). In addition, the existence of information or knowledge about a clear vision and mission in public relations in an educational institution is urgent for achieving the expected goals of public relations, and it can be a compass in making a decision or action related to public relations. 
The goals, vision and mission of public relations in an educational institution are essential. As a journey, the image is the goal to be achieved on the trip, while the task is like the stages or ways to complete the underlying purpose of the journey. The vision and mission of public relations in an educational institution help unite all components in achieving the goals that have been aspired (Wahyudi \& Pangestuti, 2017).

In addition, the vision and mission can also be a source of inspiration in developing work, innovation, creativity, and morale to make decisions and plan and implement activities in an educational institution (Wahyudi, Hasanudin \& Pangestuti, 2020). An institution whose performance is all based on the vision and mission that has been prepared, then the institution will be directed, focused and measurable, including the vision and mission in public relations (Wang, 2006). On the other hand, an institution that is not based on an image and mission or already has a vision and mission but is not understood by its members can be disoriented and not run well. For this reason, the goals, vision and mission of public relations in an educational institution are urgent. Before presenting the goals, vision and mission of public relations in educational institutions, it is first explained in general about what is meant by public relations.

\section{Research Methods}

In this study, the types of case studies are qualitative. Interviews and literary studies, field observations, and documentation were used for data collection techniques in this study. In this study, the analysis coincided with data collection on the ground. The investigator reduces data obtained in the field by analyzing the data, sorting each information by focusing on research, and drawing conclusions in each direction. Triangulation techniques (sources and methods/technics), observations and member checks are applied to check the validity of the data used in this study.

\section{Results and Discussion}

\subsection{Community Influence on Schools}

The influence of the community on the school as a social, educational institution is powerful and affects the individuals in the school environment. The school environment is a complex society, consisting of various levels of organization that complement each other and are unique due to diverse cultural dimensional backgrounds. Complex organizations consist of small groups with collective characteristics with different expectations of school policies, such as goals, objectives, program curriculum, etc. Therefore, improving and heightening public attention to schools can be done by involving parents and the community in school education. The main point of developing effective participation with the local community is to enable parents and residents to participate actively and meaningfully in academic instruction in Indonesia.

The cooperative relationship between the school and the community encourages parents to be actively involved in schools' education and teaching process through collaboration with teachers in planning educational programs both individually and collectively. Effective communication between schools and the community is possible because parents and the community closely participate with teachers and monitor the development of students towards the achievement of educational, social, and personality values both in the short and long term.

Effective participation between the community and schools is needed to achieve the success of an educational institution. The growth and cognitive development of students in 
schools are primarily determined by the following: 1) There is a powerful influence of family and community encouragement on schools; 2) The existence of attitudes and household and family life; 3 ) There is a positive attitude from students towards families and households; 4) The role of parents as developers who keep away negative attitudes towards the existence of schools and education, as well as concern and feelings of interest in the school curriculum and teachers; 5) The role and community leaders in creating public relations (public relations) with schools.

In principle, community leaders play a huge role in creating school-community relations. Therefore, schools must establish close cooperation with community leaders, including formal community leaders, to foster education in schools. However, the association is not so easy to realize because many other things must be considered. To recognize this partnership, educational institutions have established bodies whose function is to promote and activate community leaders to advance educational institutions. The strategy used is to attract the community's attention by improving the education process and fostering the morality and behaviour of students carried out by teachers. The trick is that teachers must work well, set an example for students, and instil religious values, morality, and science perfectly and effectively.

Working capital and working methods like that will be able to create students or graduates as expected. This school's work performance will attract more public attention. This public attention will be the initial capital for increasing support for close cooperation between the community and schools. Likewise, the teacher's treatment of students in teaching is essential in supporting and determining the school's relationship with the district. Teacher treatment centred on classroom progress is a source of community respect and trust in the school.

This strategy follows the reality of life in the community because the community tries to send their children to quality schools (favourite). Because schools are operationally advanced and have a good image in the community's eyes, it is not difficult to establish close relationships with the district. In addition to utilizing teachers to improve school relations with the community, school managers (principals) are also expected to raise the spirit of liaison bodies of educational institutions with the district, such as school committees. With a good approach, the school committee tries to make the agency actively participate in school activities, for example, by sending information on educational institutions regularly, presenting problems encountered, compiling curricula and so on.

In addition, it is necessary to form another community group which is expected to help schools improve their relationship with the community. The group is alumni, specifically for universities that are a separate group together with other groups. He is expected to work together to assist school institutions in establishing cooperative relationships with the community.

\subsection{Public Relations Management Pattern}

In management activities, there is an element of communication. Relations with the community as an operative management activity carry the burden of realizing some of the outgoing communication activities. Ties with the community are carried out with publicity about work organization activities that outsiders should widely know. Activities are carried out by disseminating information and providing information to create the best possible understanding with the broader community regarding the school's tasks and functions, including activities that are currently, have been and will be carried out based on the volume and workload. The pattern of harmonious relations between schools and the community as a result of cooperation will create the following: 1) There is mutual 
understanding between the school and the community; 2) There are activities to help each other because they know the benefits, meaning and importance of each other's roles; 3) The existence of close cooperation with each party and a sense of responsibility or the success of the other party's business.

This situation is a manifestation of the community's support for the efficiency and effectiveness of implementing cooperation that is provided consciously and voluntarily. Such relationships arise as a result of working relations with the community who have provided information so that they understand the importance of the existence of the school organization for the community.

The main tasks or workload of a school regarding its relationship with the community are 1) People who need it; 2) Assisting leaders with their duties cannot directly provide information to people who need it; 3) Assist the leadership in preparing materials about the problems and information to be conveyed that attracts the attention of the public at a particular time; 4) Assisting leaders in developing plans and follow-up activities related to services to the community as a result of reciprocal communication with external parties that can foster expectations or improve policies or activities that the school has carried out. To carry out the work pattern, it must be carried out based on the following concepts; 5) Objective and compatible. All information or news conveyed to the public must be a ritual of the school concerned; 6) An orderly and disciplined organization. School relations with the community will only function if the main tasks with the school organization run smoothly and effectively and have effective internal and external working relationships as well; 7) Relationships must be encouraging the emergence of a desire to participate and participate in providing reasonable support from the community; 8) Continuity of information. According to their needs continuously, public relations must strive to obtain information; 9) Pay attention to public opinion. Responses that arise among the public as a back effect of the information submitted must receive real and full attention.

\subsection{Target Public Relations in Educational Institutions}

The term "target" in the article can be seen from two sides: the target as a goal and the target as an object/user or recipient of this public relations activity. The targets of public relations (as a goal) in educational institutions, namely: 1) Develop an understanding to the public about the aims and objectives of educational institutions; 2) Provide program assessments to the community to meet the needs of educational institutions; 3) Establish and improve harmonious relationships between parents and teachers in meeting the needs of students; 4) Build a positive impression and maintain trust in educational institutions; 5) Informing the public about the program plans and activities of educational institutions; 6) Seek assistance and support for the maintenance and improvement of educational institution programs; 7) Educational institutions as a service provider of satisfying services to customers (students, families and communities); 8) To increase creativity in seeking alternative education funds in the form of collaboration with other institutions.

\subsection{Vision and Mission of Public Relations in Educational Institutions}

The vision is to realize: 1) Availability of all educational information for all parties; 2) Availability of educational information as a form of transparency and accountability in the implementation of education; 3) Availability of educational information that can encourage public participation in the implementation of education; 4) Availability of educational information that can improve the public image of the institution, and 5) The establishment of good relations and understanding with all education stakeholders. 
As for the general mission of public relations in educational institutions, namely: 1) Building public trust in educational institutions; 2) Creating public relations as a professional institution in the field of information and public relations; 3) Availability of various educational information and public relations services that are needed and easily accessible to the public and education stakeholders; 4) Creating a relationship and understanding with the principle of mutual benefit between the institution and the mass media; 5) Build a positive image of the institution is entering the future era; 6) Fostering synergistic communication between educational institutions and the community, and 7) Building responsive institutions to community dynamics.

\subsection{Development of the Vision and Mission of Public Relations in Educational Institutions Based on Customer Satisfaction}

Suppose it is associated with customer satisfaction in educational institutions. In that case, it can be understood as a response or response from academic customers such as students, guardians of students, the community, and services or what has been provided by the educational institution. It also relates to the purchase or reuse and invites others to use the products and services produced by education. This happens partly due to the customer delivered value (the value received by the customer). Mathematically, satisfaction is the difference between Total Customer Value and Total Customer Cost. Total Customer Value is the sum of all the sacrifices a person makes to obtain goods and services. That is the comparison between the gift of time, effort and money spent with the value of the benefits received.

Some opinions and theories about customer satisfaction can be shown as follows: First, Contrast Theory which assumes that consumers will compare the actual product performance with the expectations of the purchasers, where if the actual performance is greater than or equal to expectations, the customer will be satisfied and vice versa if the actual performance is greater than or equal to expectations, the customer will be happy and vice versa. Actual performance is lower than expectations; then, consumers will experience dissatisfaction. Second, Assimilation Theory states that post-purchase evaluation is a positive function of the expectations of para-purchase consumers; consumers tend to perceptually distort the difference between expectations and performance towards initial expectations so that deviations from their expectations tend to be accepted by the consumers concerned. Third, Assimilation-contras Theory holds that the occurrence of the assimilation effect or contrast effect is a function of the level of the gap between expected performance and actual performance. If the hole is large, consumers will enlarge the opening. In other words, the accepted timeframe is passed, then the gap between expectations and performance will become significant, so that is where the contrast effect applies.

Thus, educational institutions are essentially service organizations that also require marketing principles so that educational institutions should have a customer orientation, which means that organizational functions that serve customers are accommodated. Processes such as research and development consist of Collecting, processing, and updating databases; these roles and functions are managed by the public relations of the educational institution. Thus, public relations should be part of the structure of the educational institution. In addition, educational institutions, including public relations, also need to have a customer-oriented culture, such as a culture of service, friendship, proactivity, friendliness, cooperation, etc.

Customer-oriented educational institutions generally have the following characteristics or indicators: 1) Have a program that aims to identify customer 
expectations; 2) Consistently measure customer satisfaction; 3) Designing services following customer expectations; 4) Communicating effectively; 5) Have a proactive personal profile; 6) Friendly, serving, enthusiastic, and trustworthy; 7) Have an organizational structure that accommodates customer service; and 8) Developing participatory management.

Based on some of the explanations above, including indicators of customer-oriented educational institutions, this can guide public relations practitioners in compiling and developing the vision and mission of public relations. The vision and mission of public relations, which introduces the educational institution itself without paying attention to the expectations and needs of customers of educational services, will certainly have different results when the formulation and development of the vision and mission of public relations are based on the needs and expectations of the market/customers. When the vision and mission of public relations are also based on customer satisfaction, this will help and make it easier for educational institutions to build positive public opinion. That's why the development of the vision and mission of public relations based on customer satisfaction needs to be launched.

After developing the vision and mission of public relations based on customer satisfaction, it is necessary to measure customer satisfaction. There are several ways to measure customer satisfaction, including customers in educational institutions, namely: 1) Complaint and Suggestion System, information from suggestions and complaints will be used as data in anticipating and developing educational institutions; 2) Customer Satisfaction Surveys, the level of customer complaints are used as data in measuring satisfaction, this can be through interviews, surveys, mail, telephone or questionnaires; 3 ) Ghost Shopping, by sending people to make observations/checks at other educational institutions or their institutions to see the advantages and disadvantages of their services; 4) Lost Customer Analysis, namely contacts made to customers who have switched to other educational institutions to be used as performance improvements in increasing satisfaction.

In addition, if there is customer dissatisfaction with the services provided at an educational institution, this can generally be caused by several factors, including Not following expectations with the reality experienced: 1) Dissatisfaction with services during the process of enjoying services; 2) Unsatisfactory behaviour of personnel; 3) Unfavorable atmosphere and environmental conditions; and 4) Costs/costs are too high, either because of distance, time or the price/cost of education is too high. Promotion does not match reality. From the description of the vision and mission of public relations based on customer satisfaction above, it is hoped that it can be an alternative for the development of existing public relations in an educational institution so that the expected public relations goals can be achieved better.

\section{Conclusion}

Good public relations or public relations in educational institutions is public relations that can implement the goals, visions and missions that have been set in real terms. But are used as the basis for carrying out these public relations duties properly. To make it happen, the vision and mission of public relations in educational institutions need to be supported and the active role of various components in the educational institution, both principals, teachers, including all members of the school or educational institution. Finally, so that positive public opinion towards an educational institution can be realized, the development of the vision and mission of public relations in educational institutions based on customer satisfaction can be used as a choice for the achievement of the expected goals. 


\section{References}

Bello, F. G., Lovelock, B., \& Carr, N. (2017). Constraints of community participation in protected area-based tourism planning: The case of Malawi. Journal of Ecotourism, 16(2), 131-151.

Carlson, J., Wyllie, J., Rahman, M. M., \& Voola, R. (2019). Enhancing brand relationship performance through customer participation and value creation in social media brand communities. Journal of Retailing and Consumer Services, 50, 333-341.

Di Maddaloni, F., \& Davis, K. (2017). The influence of local community stakeholders in megaprojects: Rethinking their inclusiveness to improve project performance. International journal of project management, 35(8), 1537-1556.

Ferguson, M. A. (2018). Building theory in public relations: Inter-organizational relationships as a public relations paradigm. Journal of Public Relations Research, 30(4), 164-178.

Filipe, A., Renedo, A., \& Marston, C. (2017). The co-production of what? Knowledge, values, and social relations in health care. PLoS biology, 15(5), e2001403.

Haldane, V., Chuah, F. L., Srivastava, A., Singh, S. R., Koh, G. C., Seng, C. K., \& LegidoQuigley, H. (2019). Community participation in health services development, implementation, and evaluation: A systematic review of empowerment, health, community, and process outcomes. PloS one, 14(5), e0216112.

Hasanudin, H. (2021). The Effect of Inflation, Exchange, SBI Interest Rate and Dow Jones Index on JCI on IDX 2013-2018. Budapest International Research and Critics Institute (BIRCI-Journal): Humanities and Social Sciences, 4(2), 2063-2072.

Hasanudin, H., \& Awaloedin, D. T. (2020). Pengaruh Current Ratio, Debt To Equity Ratio Dan Net Profit Margin Terhadap Return Saham Pada Perusahaan Jasa Sub Sektor Telekomunikasi Yang Terdaftar di BEI Periode 2012-2018. Jurnal Rekayasa Informasi, 9(1), 6-19.

Irmayani, H., Wardiah, D., \& Kristiawan, M. (2018). The strategy of SD Puri in improving educational quality. International Journal of Scientific \& Technology Research, 7(7), 113-121.

Ishimaru, A. M. (2019). From family engagement to equitable collaboration. Educational Policy, 33(2), 350-385.

Ji, Y. G., Li, C., North, M., \& Liu, J. (2017). Staking reputation on stakeholders: How does stakeholders' Facebook engagement help or ruin a company's reputation?. Public Relations Review, 43(1), 201-210.

Kapera, I. (2018). Sustainable tourism development efforts by local governments in Poland. Sustainable cities and society, 40, 581-588.

Kumar, V., \& Nanda, P. (2019). Social media in higher education: A framework for continuous engagement. International Journal of Information and Communication Technology Education (IJICTE), 15(1), 97-108.

Nurwulandari, A., \& Adnyana, I. (2019). Did Inter-Regional Trade Agreements Bring Mutual Benefits? An Empirical Scheme of Indonesian Commodity Exports in AseanChina Free Trade Area. International Journal of Financial Research, 10(6), 241-249.

Nurwulandari, A., Hasanudin, H., \& Melati, M. (2021). Market Reactions on Corporate Actions in Growing and Nongrowing Energy-Consuming Companies. International Journal of Energy Economics and Policy, 11(3), 290-295.

Oakes, J., Maier, A., \& Daniel, J. (2017). Community Schools: An Evidence-Based Strategy for Equitable School Improvement. National Education Policy Center. 
Sadiqi, Z., Trigunarsyah, B., \& Coffey, V. (2017). A framework for community participation in post-disaster housing reconstruction projects: A case of Afghanistan. International Journal of Project Management, 35(5), 900-912.

Sidiq, R. S. S., \& Jalil, A. (2021). Virtual World Solidarity: How Social Solidarity is Built on the Crowdfunding Platform Kitabisa. com. Webology, 18(1).

Sidiq, R. S. S., \& Achmad, R. W. W. (2020). Gender aspects in remote indigenous community empowerment program in Indonesia. Journal of Advanced Research in Dynamical and Control Systems, 12(6), 2104-2109. https://doi.org/10.5373/JARDCS/V12I6/S20201172

Singgalen, Y. A., Sasongko, G., \& Wiloso, P. G. (2019). Community participation in regional tourism development: a case study in North Halmahera Regency-Indonesia. Insights into Regional Development, 1(4), 318-333.

Sullivan, D. P., Winsnes, C. F., Åkesson, L., Hjelmare, M., Wiking, M., Schutten, R., ... \& Lundberg, E. (2018). Deep learning is combined with massive-scale citizen science to improve large-scale image classification. Nature Biotechnology, 36(9), 820-828.

Theadom, A., Starkey, N., Barker-Collo, S., Jones, K., Ameratunga, S., Feigin, V., \& BIONIC4you Research Group. (2018). A population-based cohort study of the impacts of mild traumatic brain injury in adults four years post-injury. PLoS One, 13(1), e0191655.

Wahyudi, S., \& Pangestuti, I. R. D. (2017). Managing the Pension Fund to Improve Portfolio Performance: An Empirical Study on Employer Pension Funds In Indonesia.

Wahyudi, S., Hasanudin, H., \& Pangestutia, I. (2020). Asset allocation and strategies on investment portfolio performance: A study on implementing employee pension fund in Indonesia. Accounting, 6(5), 839-850.

Wang, J. (2006). Managing national reputation and international relations in the global era: Public diplomacy revisited. Public relations review, 32(2), 91-96. 